\section{АНАЛІЗ СТАНУ ДОРОЖНЬОГО ГОСПОДАРСТВА ТА ПРОГРАМИ «ВЕЛИКЕ БУДІВНИЦТВО"}

\author{
KONONOV S., \\ Post-graduate Student, \\ Donetsk State University of \\ Management
}

\section{ANALYSIS OF THE STATE OF THE ROAD ECONOMY AND THE "GREAT CONSTRUCTION" PROGRAM}

\author{
KOHOHOB C. O., \\ аспірант, \\ Донецький державний університет \\ управління
}

У статті визначено Представлено структуру

сутність дорожнього господарства. автомобільних доріг загального користування. Проаналізовано сучасний стан українських доріг. Визначено джерела фінансування дорожнього фонду України. Наведено загальний обсяг дорожнього фонду. Розкрито мету, задачі та принципи проєкту «Велике будівництво». Проаналізовано обсяги дорожніх робіт та їх фінансування за період 2015-2020 рр. Представлено перелік та обсяг оновлених доріг України на кінець 2020 р. Визначено ТОП-5 підрядників з ремонтів, будівництву та реконструкції. Зазначено позитивний вплив розвитку дорожнього господарства на працевлаштування населення країни.

Ключові слова: дорожнє господарство, інфраструктура, будівництво, підрядник, автомобільні дороги.

В статье определена сущность дорожного хозяйства. Представлена структура автомобильных дорог общего пользования. Проанализировано современное состояние украинских дорог. Определены источники финансирования дорожного фонда Украины. Приведен общий объем дорожного фонда. Раскрыты цели, задачи и принципы проекта «Большая стройка». Проанализированы объемы дорожных работ и их финансирования за период 2015-2020 гг. Представлен перечень и объем обновленных дорог Украины в конце 2020 г. Определен ТОП-5 подрядчиков по ремонту, строительству и реконструкции. Отмечено положительное влияние развития дорожного хозяйства на трудоустройство населения страны.

Ключевые слова: дорожное хозяйство, инфраструктура, строительство, подрядчик, автомобильные дороги.

The article defines the essence of road management. The structure of public roads is presented. The current state of Ukrainian roads is analyzed. Sources of financing of the road fund of Ukraine are determined. The total volume of the road fund is given. The purpose, tasks and principles of the project "Large construction" are revealed. The volumes of road works and their financing for the period 2015-2020 are analyzed. The list and volume of renewed roads of Ukraine for the end of 2020 are presented. TOP-5 contractors for repairs, construction and reconstruction are determined. The positive impact of road development on the employment of the country's population is noted.

Keywords: road management, infrastructure, construction, contractor, highways.

Постановка проблеми. Стійкий сталий розвиток будь-якого регіону, територіальної громади та країни в цілому неможливо забезпечити без належної дорожньої інфраструктури. Сучасна держава не може існувати без розвинутого дорожнього господарства, яке сьогодні забезпечує реалізацію бізнес зв'язків, 
туристичного потенціалу, функціонування виробництва та підвищення якості життя населення. Досвід європейських країн свідчить про те, що розвиненість дорожньої інфраструктури підвищує міжнародний взаємозв'язок між, який впливає на рівень розвитку економіки в країні. Отже, враховуючи актуальність даної тематики та негативний стан дорожнього господарства в Україні розпочато масштабну державну програму «Велике будівництво», одним з напрямків, якої $€$ покращення дорожньої інфраструктури в країні.

Аналіз останніх досліджень і публікацій. Актуальні питання дорожнього господарства $\epsilon$ предметом аналізу та досліджень багатьох науковців й експертів цієї галузі (Букатюк У., Бурмака М., Мельник М. Шинкаренко В. та інші). Однак, враховуючи динамічність подій які відбуваються у дорожній галузі та економіці країни в цілому виникає потреба постійного аналізу та моніторингу даної сфери.

Метою статті $€$ аналіз сучасного стану дорожнього господарства України та особливості реалізації проєкту «Велике будівництво».

Дорожнє господарство $€$ одним 3 ключових напрямів ефективного розвитку країни, тому необхідно приділяти значну увагу аналізу та контролю сучасного стану даної інфраструктури.

Так, на думку В.Г. Шинкаренка та М.М. Бурмаки, дорожнє господарство можна визначити як єдиний виробничо-господарський комплекс, до складу якого входять автомобільні дороги та інженерні споруди на них, а також підприємства й організації, що здійснюють будівництво, реконструкцію, ремонт, експлуатаційне утримання автомобільних доріг та іншу діяльність, пов'язану із забезпеченням функціонування й розвитку мережі автомобільних доріг [1].

У Законі України «Про джерела фінансування дорожнього господарства України» [2] визначено поняття «автомобільні дороги загального користування та сільські дороги України». А саме, це дороги державного та місцевого значення, що забезпечують міжнародні та внутрішньодержавні перевезення вантажів і пасажирів 3 урахуванням адміністративно-територіального поділу держави та з'єднують ії населені пункти, $є$ складовою частиною єдиної транспортної системи держави.

На рис. 1. представлено структуру автомобільних доріг загального користування.

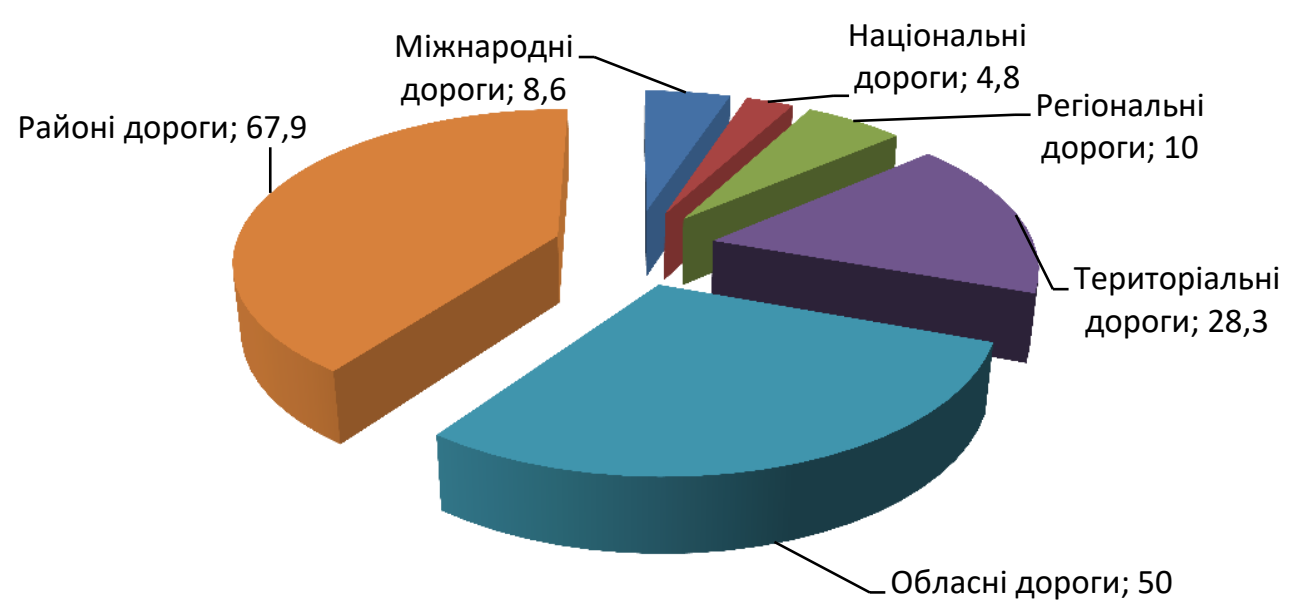

Рис. 1. Структура автомобільних доріг загального користування, тис. КM. [3] 
Аналіз рис. 1. дозволяє зробити висновок, що питому вагу у структурі автомобільних доріг загального користування складають місцеві дороги (районі дороги та обласні дороги) 69,5\%, це становить 117,6 тис. км. В свою чергу, державні дороги складають 52 тис. км.

Транспортно-експлуатаційний стан більшості автомобільних шляхів України не відповідає сучасним вимогам і потребує капітального ремонту з урахуванням соціально-економічних потреб регіонів. За оцінками експертів Світового економічного форуму, Україна займає 132 місце у світі за рівнем розвитку автомобільних доріг. До того ж понад 9,6 тис. мостів за технічними параметрами не відповідають вимогам сучасних норм і фактичному навантаженню, 1923 мости потребують термінового ремонту, а 86 мостів перебувають в аварійному стані [4].

Негативна ситуація зі станом українських доріг, в першу чергу, пов'язана з браком фінансування. Відповідно до даних Міністерства інфраструктури, 90\% вітчизняних доріг продовж 30 років майже не ремонтується. Так 51,1\% автомобільних доріг загального користування не відповідають вимогам за рівністю, а 39,2\% - за міцністю.

Водночас з 1 січня 2018 року чинними стали Закон України «Про внесення змін до Закону України «Про джерела фінансування дорожнього господарства України» щодо удосконалення механізму фінансування дорожньої галузі» та Закон України «Про внесення змін до Бюджетного кодексу України щодо удосконалення механізму фінансового забезпечення дорожньої галузі». Цими Законами передбачено створення Державного дорожнього фонду у спеціальному фонді Державного бюджету України [4].

Згідно зі ст. 242 та 29 Бюджетного кодексу України та Закону України «Про джерела фінансування дорожнього господарства України» державний дорожній фонд фінансується за рахунок [5]:

1) акцизного податку з вироблених в Україні пального i транспортних засобів (окрім акцизного податку 3 вироблених в Україні підакцизних товарів (продукції), що сплачується платниками, які зареєстровані в Автономній Республіці Крим);

2) акцизного податку з ввезених на митну територію України пального і транспортних засобів; до них;

3) ввізного мита на нафтопродукти і транспортні засоби та шини

4) плати за проїзд автомобільними дорогами транспортних засобів та інших самохідних машин і механізмів, вагові або габаритні параметри яких перевищують нормативні;

5) плати за проїзд платними автомобільними дорогами загального користування державного значення;

6) державних запозичень, залучених для реалізації інвестиційних проєктів на розвиток мережі та утримання автомобільних доріг загального користування;

7) концесійних платежів - у разі передачі новозбудованої автомобільної дороги загального користування державного значення у концесію;

8) інших надходжень, визначених законом про Державний бюджет України.

Загальний обсяг дорожнього фонду розподіляється [6]: 
$60 \%$ на фінансування робіт, пов'язаних із автомобільними дорогами загального користування державного значення;

$35 \%$ на фінансування робіт, пов'язаних із автомобільними дорогами загального користування місцевого значення;

$5 \%$ на фінансове забезпечення заходів із забезпечення безпеки дорожнього руху відповідно до державних програм.

Першого березня 2020 року в Україні стартував президентський проєкт «Велике будівництво». Метою якого є масштабна розбудова якісної інфраструктури України. У межах проєкту заплановано будівництво, реконструкцію таких інфраструктурних об'єктів як: дороги, школи, дитячі садки, центри екстреної медичної допомоги та стадіони.

На рис. 2. представлено основні задачі проєкту «Велике будівництво» на 2020 р.

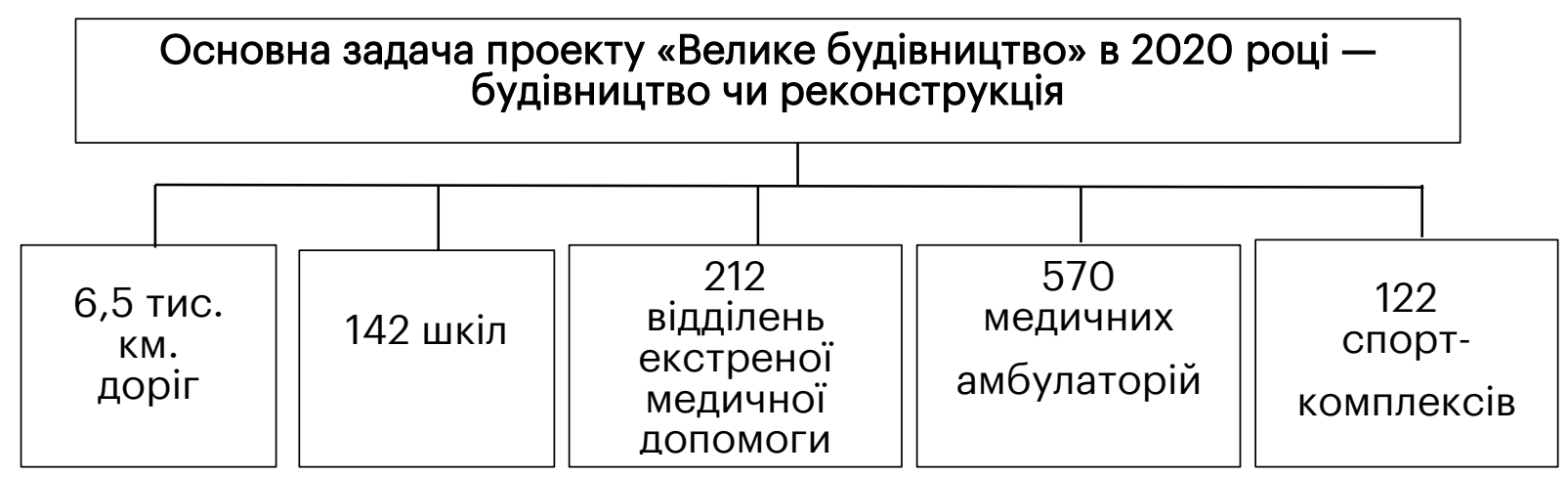

Складено автором на базі джерела [7]

Рис. 2. Основні задачі проєкту «Велике будівництво» у 2020 році

Реалізація проєкту «Велике будівництво» відбувається за такими принципами:

- енергоефективність;

- висока якість;

- інклюзивність;

- націленість проекту на кожного українця як клієнта.

Далі розглянемо більш детально особливості виконання проекти «Велике будівництво» в аспекті будівництва та реконструкції доріг.

Щоб реалізувати це масштабне будівництво, уряд вирішив виділити на близько 113 млрд гривень з кількох джерел - Дорожнього фонду, кредитів від міжнародних фінансових організацій, частини коштів, які Україна отримала від Газпрому за рішенням Стокгольмського арбітражу, а також з кредиту в українських банках. В оновленому держбюджеті зберігся такий обсяг фінансування, його не урізали, як деякі інші галузі, у зв'язку з пандемією корона вірусу [8].

На рис. 3. представлено обсяги дорожніх робіт та їх фінансування за період 2015-2020 рр. 


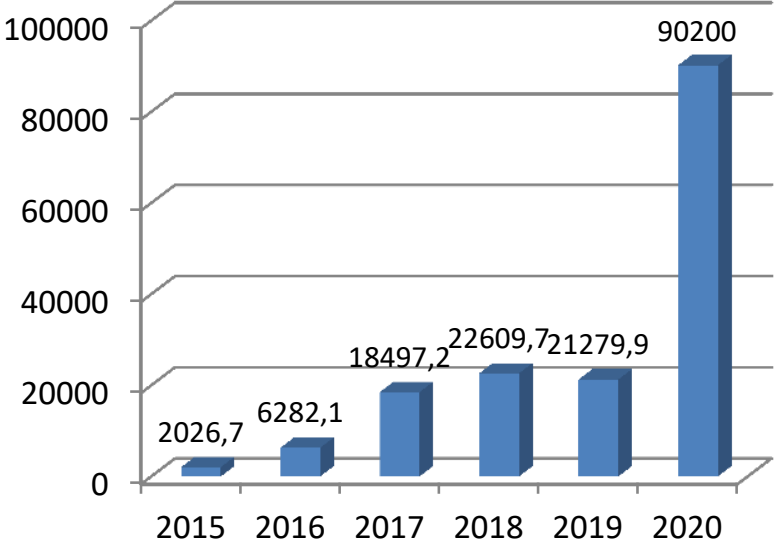

а) кошти, млн грн

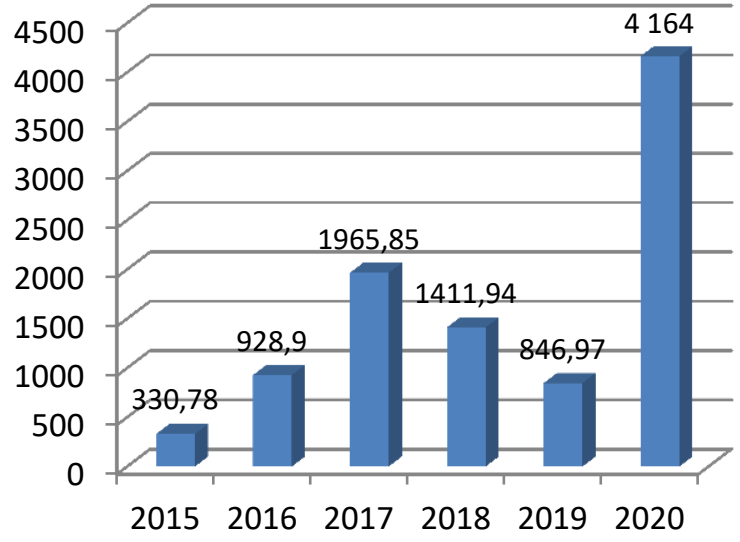

б) дороги, км

Рис. 3. Обсяги дорожніх робіт та їх фінансування за період 2015-2020 pp.

Аналіз наведених даних на рис. 3. показує щорічне зростання обсягу коштів спрямованих на дорожні роботи за 2015-2020 рр. Не значне зниження фінансування відбулось лише у 2019 році. В свою чергу, динаміка побудованих та відремонтованих доріг має циклічний характер. У 2020 році відбувається ризьке збільшення як обсягу дорожніх робіт, так й їх фінансування. В першу чергу, це пов'язано з початком реалізації проєкту «Велике будівництво».

Для більш детального розуміння масштабності проєкту «Велике будівництво», реалізація якого буде відбуватися впродовж п'яти років, представимо обсяги дорожніх робіт, які було здійснено на кінець 2020 р. по окремим територіям країни (табл. 1).

Таблиця 1

Оновлені дороги України на кінець 2020 р. [9]

\begin{tabular}{|l|c|}
\hline \multicolumn{1}{|c|}{ Ділянки доріг } & Обсяг, км \\
\hline М-03 Київ - Харків - Довжанський & 216,5 \\
\hline $\begin{array}{l}\text { М-12 Стрий - Тернопіль - Кропивницький - Знам'янка (через м. } \\
\text { Вінниця) }\end{array}$ & 94,7 \\
\hline М-19 Доманове (на м. Брест) - Ковель - Чернівці - Тереблече & 115 \\
\hline М-18 Харків - Сімферополь - Алушта - Ялта & 93,6 \\
\hline М-04 Знам'янка - Луганськ - Ізварине & 32,4 \\
\hline М-21 Виступовичі - Житомир - Могилів Подільський & 75,4 \\
\hline Маршрут від КПП «Станиця Луганська» до Сєверодонецка & 125 \\
\hline Н-01 Київ - Знам'янка & 35,8 \\
\hline Н-07 Київ - Суми - Юнаківка & 81,5 \\
\hline Н-08 Бориспіль - Кременчук - Дніпро - Запоріжжя - Пологи - \\
Маріуполь
\end{tabular}




\begin{tabular}{|l|c|}
\hline \multicolumn{2}{|c|}{ Продовження табл. } \\
\hline Н-09 Мукачево - Рахів - Івано-Франківськ - Львів & 133,4 \\
\hline Н-11 Дніпро - Миколаїв (через м. Кривий Ріг) & 92,2 \\
\hline Н-13 Львів - Самбір - Ужгород & 63,8 \\
\hline Н-14 Олександрівка - Кропивницький - Миколаїв & 67,9 \\
\hline Н-16 Золотоноша - Черкаси - Сміла - Умань & 60,3 \\
\hline Н-23 Кропивницький - Кривии Ріг - Запоріжжя \\
\hline Н-30 Василівка - Бердянськ & 103 \\
\hline Н-31 Дніпро - Решетилівка & 114 \\
\hline Р-24 Татарів - Косів - Коломия - Борщів - Кам'янець-Подільський & 75,1 \\
\hline Р-51 Мерефа - Лозова - Павлоград & 35 \\
\hline Р-67 Чернігів - Ніжин - Прилуки - Пирятин & 60,7 \\
\hline Р-73 /Н-08/ Нікополь (у межах Дніпропетровської області) & 43,5 \\
\hline Т-07-18 Нижні ворота - Воловець - Міжгір'я & 45,2 \\
\hline Т-14-16 Львів - Пустомити - Меденичі & 45 \\
\hline Т-14-02 Львів - Східниця - Пісочна & 47,5 \\
\hline
\end{tabular}

${ }^{*}$ Складено автором на базі джерела [9]

Таким чином, з табл. 1. видно, що оновлення доріг у 2020 році відбувається на території всіх регіонів України, це свідчить про рівномірний розвиток дорожньої інфраструктури що забезпечить позитивний ефект для всіх регіонів.

Всі дорожні роботи, які здійснюються на території України відбуваються через тендерний механізм. Однак, багато експертів в галузі дорожньої інфраструктури, зазначають, що у тендерах за рахунок державного фінансування приймають участь переважно п'ять великих будівних компаній, а інші не є конкурентоспроможними, ті дорожні роботи, які фінансуються 3 місцевих бюджетів мають протилежну ситуацію Дану тенденцію наведено у табл. 2.

Таблиця 2

ТОП-5 підрядників з ремонтів, будівництву та реконструкції САД та ОДА

\begin{tabular}{|c|c|c|c|c|c|}
\hline \multirow{2}{*}{ Підрядні компанії } & $\begin{array}{c}\text { САД (служба } \\
\text { автомобільних } \\
\text { доріг) }\end{array}$ & \multirow{2}{*}{ Підрядні компанії } & \multicolumn{2}{|c|}{$\begin{array}{c}\text { ОДА (обласна } \\
\text { державна } \\
\text { адмістрація) }\end{array}$} \\
\cline { 2 - 3 } & $\begin{array}{c}\text { млрд } \\
\text { грн }\end{array}$ & $\%$ & & $\begin{array}{c}\text { Млрд } \\
\text { грн }\end{array}$ & $\%$ \\
\hline $\begin{array}{c}\text { ТОВ «Автомагістраль- } \\
\text { Південь» }\end{array}$ & 4,823 & 31 & \multirow{2}{*}{$\begin{array}{c}\text { ТОВ } \\
\text { «остодорстрой» }\end{array}$} & 0,674 & 11 \\
\hline ТОВ «ТехнО-Буд-Центр» & 1,801 & 11 & ПП «Дорсервіс КПК» & 0,641 & 10 \\
\hline
\end{tabular}


Продовження табл. 2

\begin{tabular}{|c|c|c|c|c|c|}
\hline $\begin{array}{c}\text { TОВ «Онур констр. } \\
\text { Інтернешнл» }\end{array}$ & 1,602 & 10 & $\begin{array}{c}\text { ОАО «ДСТ №4 г. } \\
\text { Брест }\end{array}$ & 0,434 & 7 \\
\hline ТОВ «СП Автострада» & 1,537 & 10 & $\begin{array}{c}\text { ТОВ «СУАП «Інтервіас } \\
\text { Україна»» }\end{array}$ & 0,225 & 4 \\
\hline Ozaltin itvsas & 1,087 & 7 & ТОВ «БК Євродор» & 0,221 & 4 \\
\hline Решта підрядників & 4,967 & 31 & Решта підрядників & 4,045 & 64 \\
\hline
\end{tabular}

${ }^{\star}$ Складено автором на базі джерела [10]

Отже, з табл. 2. видно, що САД з підрядними організаціями уклав договорів з будівництва, ремонту, реконструкції доріг на суму 15,9 млрд грн, а ОДА з підрядними організаціями на аналогічні види робіт уклала договори на суму 6,2 млрд грн. Серед підрядних організацій, які працюють з САД найбільшу долю договорів складено 3 ТОВ «Автомагістраль-Південь» (31\%). Відповідно до укладених договорів між ОДА та підрядних компаній, переважна більшість партнерських відносин відбувається не з основними компаніями (55\%). Тобто на місцевому рівні відбувається більш активна конкурентна боротьба між будівельними підприємствами.

Враховуючи вище наведене, ще одним важливим моментом у процесі реалізації проєкту «Велике будівництво» $\epsilon$ те, що загалом дорожнє будівництво триває по всій країні, даючи роботу тисячам українців. За даними Укравтодору, з травня 2020 р. на об'єктах «Великого будівництва» працевлаштувалися 7729 дорожників; а вже, за даними Кабінету Міністрів, станом на початок липня 2020 р. будівництво доріг вже допомогло створити понад 10 тисяч робочих місць. Аби зробити пошук робітників ефективнішим, Кабмін у партнерстві 3 robota.ua запустив онлайн-інструмент для пошуку роботи у дорожній галузі - «Дороги та робота» [8].

Висновки і перспективи подальших досліджень. Таким чином дорожне господарство $€$ стратегічною галуззю країни. Якісний розвиток дорожньої інфраструктури дає можливість підвищити соціально-економічний рівень будь-якої країни. Це пов'язано з тим, що виникає можливість ефективно реалізовувати логістичні системи, які дозволяють на підприємствах покращувати товарообіг, зміцнювати бізнес зв'язки, розвивати різні види послуг (наприклад туристичні) та інше. Том враховуючи важливість дорожнього господарства та незадовільний стан 90\% українських автомобільних доріг актуальним став масштабний проєкт «Велике будівництво», який було розпочато з першого березня 2020 р. Даний проект вирішує не тільки проблеми якості доріг та покращення дорожньої інфраструктури в цілому, але й частково вирішує проблемне питання для країни - працевлаштування. Незважаючи на позитивні аспекти від реалізації проєкту «Велике будівництво», залишаються питання проблемного характеру: фінансування, система контролю за якістю виконаних робіт, прозорість у виборі підрядників та інше. Аналіз цих питань може стати метою подальших наукових досліджень. 
Література:

1. Шинкаренко В.Г., Бурмака М. М. Галузеві особливості розвитку дорожнього господарства. Економіка транспортного комплексу, 2011. Вип. 18. С. 143-153.

2. Про джерела фінансування дорожнього господарства України: Закон України від 18 вересня 1991 року № 1562-XII. URL: https://zakon.rada.gov.ua/laws/show/1562-12\#Text.

3. Технічний стан автомобільних доріг загального використання. Міністерство інфраструктури URL: https://mtu.gov.ua/content/tehnichniystan-avtomobilnih-dorigavtomobilnih-dorig-zagalnogovikoristannya.html.

4. Мельник В.І. Особливості фінансування галузі дорожнього господарства України в умовах децентралізації. Економіка та управління національним господарством, 2020. Вип. 42. С. 91-96.

5. Аналіз формування та використання коштів державного дорожнього фонду у $2018-2019$ pp. URL: https://feao.org.ua/products/dorozhniy-fond-2018-2019/

6. Державний дорожній фонд. Особливості формування та використання коштів. URL: https://decentralization.gov.ua/uploads/att achment/document/66/Doroga-

Fond12 \%D0\%B4\%D1\%80\%D1\%83\%D0\%BA .pdf.

7. Велике будівництво. URL: https://bigbud.kmu.gov.ua/\#about

8. Дем'яненко Л. Велике будівництво: стан реалізації та оцінка експертів. URL: http://www.nbuviap.gov.ua/index.php?option=com co ntent\&view=article\&id=4975:velike-budivnitstvo-stan-realizatsiji-taotsinka-ekspertiv\&catid=8\&ltemid=350.

9. «Укравтодор» у 2020. Аналіз кілометрів, підходів і амбітних планів. URL: https://daily.rbc.ua/ukr/show/ukravtodor-2020-analizkilometrov-podhodov-1608548565.html.

10. Букатюк У. Дороги Зеленського: п'ять проблем великого будівництва. URL:https://project.liga.net/projects/large construction/.

References:

1. Shynkarenko V. Gh., Burmaka M. M. Ghaluzevi osoblyvosti rozvytku dorozhnjogho ghospodarstva. Ekonomika transportnogho kompleksu, 2011. Vyp. 18. S. 143-153.

2. Pro dzherela finansuvannja dorozhnjogho ghospodarstva Ukrajiny: Zakon Ukrajiny vid 18 veresnja 1991 roku \# 1562-XII. URL: https://zakon.rada.gov.ua/laws/show/1562-12\#Text.

3. Tekhnichnyj stan avtomobiljnykh dorigh zaghaljnogho vykorystannja. Ministerstvo infrastruktury Ukrajiny. URL: https://mtu.gov.ua/content/tehnichniystan-avtomobilnih-dorigavtomobilnih-dorig-zagalnogovikoristannya.html.

4. Meljnyk V.I. Osoblyvosti finansuvannja ghaluzi dorozhnjogho ghospodarstva Ukrajiny $v$ umovakh decentralizaciji. Ekonomika ta upravlinnja nacionaljnym ghospodarstvom, 2020. Vyp. 42. S. 91-96.

5. Analiz formuvannja ta vykorystannja koshtiv derzhavnogho dorozhnjogho fondu u 2018-2019 rr. URL: https://feao.org.ua/products/dorozhniy-fond-2018-2019/.

6. Derzhavnyj dorozhnij fond. Osoblyvosti formuvannja ta vykorystannja koshtiv. URL: https://decentralization.gov.ua/uploads/att achment/document/66/Doroga-

Fond12_\%D0\%B4\%D1\%80\%D1\%83\%D0\%BA_.pdf. 
7. Velykebudivnyctvo. URL: https://bigbud.kmu.gov.ua/\#about

8. Dem'janenko L. Velyke budivnyctvo: stan realizaciji ta ocinka ekspertiv. URL: http://www.nbuviap.gov.ua/index.php?option=c om_content\&view=article\&id $=4975$ :velike-budivnitstvo-stan-realizatsijita-otsinka-ekspertiv\&catid=8\&ltemid=350.

9. "Ukravtodor" u 2020. Analiz kilometriv, pidkhodiv i ambitnykh planiv. URL: https://daily.rbc.ua/ukr/show/ukravtodor-2020analiz-kilometrov-podhodov-1608548565.html.

10. Bukatjuk U. Doroghy Zelensjkogho: p'jatj problem velykogho budivnyctva. URL:https://project.liga.net/projects/large construction/.

The purpose of the article is to analyze the current state of the road industry of Ukraine and the peculiarities of the project "Large Construction". It was noted in the paper that the development of industry, services, business and the economy as a whole depends on the state and development of the road industry. The essence and subjects of road management are revealed. In accordance with the current legislation of Ukraine, the concept of "public roads and rural roads of Ukraine" is defined. The structure of public roads is presented and analyzed.

It is noted that the transport and operational condition of most roads in Ukraine does not meet modern requirements and needs major repairs, taking into account the socio-economic needs of the regions. The Laws of Ukraine are presented, which provide for the creation in 2018 of the State Road Fund in a special fund of the State Budget of Ukraine. And the sources of financing of the State Road Fund have been identified. The distribution of the total volume of the road fund is presented. Given the negative trend in the development of the economy, the relevance and timeliness of the implementation of the project "Large-scale construction", which involves the construction, repair and reconstruction of such infrastructure facilities as roads, schools, sports complexes, medical facilities. The main sources of funding for the Big Construction project are revealed. The volumes of road works and their financing for the period 2015-2020 are analyzed. The list and volumes of the updated roads of Ukraine for the end of 2020 are given. The main contractors for road repairs, construction and reconstruction are presented, the work of which is financed either from the state budget or from local budgets. According to the results of the study, a conclusion was made about the negative state of development of the road structure of Ukraine, which became a significant and necessary factor in the implementation of the state program "Large Construction". This project not only solves the problems of road quality and improvement of road infrastructure in general, but also partially solves the problem of jobs. Despite the positive aspects of the implementation of the project "Large Construction", there are still problematic issues: funding, quality control system, transparency in the selection of contractors and more. 